\title{
Morality versus the scientific evidence: The story behind Bill C-2
}

\author{
Ehsan Jozaghi \\ School of Criminology, \\ Simon Fraser University, 8888 University Drive, Burnaby, British \\ Columbia V5A 1S6, Canada. E-mail: eja2@sfu.ca
}

Pre-publication version December, 2014.

Published in:

Journal of Substance Use, 21(3), 225-227.

To link to this article: https://doi.org/10.3109/14659891.2014.987837 


\section{Morality versus the scientific evidence: The story behind Bill $C-2$}

Although recent data in Vancouver has shown a decline in the HIV and HCV rates within the IDU population - a direct consequence of effective harm reduction programs - the rest of Canada has shown an increase in the same (Ti et al., 2013). For example, recent data in Montreal, Ottawa, Toronto, and Saskatoon show high rates of HIV prevalence within the IDU population (Bayoumi \& Strike, 2012; Broadhead et al., 2002). HCV infection among IDUs in Canada is also extremely high: $70 \%$ in Montreal, 52\% (Toronto), and 60\% in Ottawa (Bayoumi \& Strike, 2012; Broadhead et al., 2002). The pattern of death from illicit drug overdose has also been a cause for major concern in Canada's major cities. For example, in Montreal and Toronto, it has been reported to be as high as 70 and 60 cases, respectively (Fischer et al., 2000; Jozaghi, 2012a). On 22 September 2003, North America's first supervised injection facility (SIF), known as 'InSite', opened its doors. Located in Vancouver's Downtown Eastside, InSite was meant to reduce the twin burdens of blood borne diseases and health-related costs (Kerr et al., 2003). So far, InSite has been visited by more than 2 million clients in the Downtown Eastside, and currently, an optimal use is being made of it (Hyshka et al., 2013; Kerr et al., 2007; Jozaghi, 2012b). At present, there are more than 15, 000 unique IDUs who are registered to use the facility - with the average user of Insite visiting the facility more than 11 times per month (Rennie, 2011). InSite offers a space for IDUs to use previously obtained illicit drugs under the medical supervision of health professionals in a hygienic and safe environment (Fast et al., 2008). Within InSite, IDUs are typically provided with sterile injection equipment. These include bottles of sterile water for injection, insulin syringes, latex condoms, alcohol swaps, disposal boxes and cookers, coffee, food, water as well as emergency care (in case of overdose) and referrals to addiction services (Wood et al., 2005). InSite is currently required to abide by strict regulations, including regulations that prohibit the sharing of drugs, assisted injections and require registration of participants (Kerr et al., 2007). Throughout a typical day at InSite - it is open $7 \mathrm{~d}$ a week from $10 \mathrm{AM}$ to $4 \mathrm{PM}-600$ injections are supervised within the 12 tiny individual booths for injections (Kerr et al., 2007).

As of 2013, 92 SIFs have been opened in 61 cities (Dooling \& Rachlis, 2010; Hyshka et al., 2013). However, InSite opened as a pilot project only after (1) overriding some of the provisions of the Controlled and Substances Act established by the Canadian Liberal federal government, and (2) obtaining recommendations from a federal task force (Dooling \& Rachlis, 2010). Furthermore, faith in InSite as a medical experiment hinged on the condition that its impact would be rigorously evaluated (Hathaway \& Tousaw, 2008). Incidentally, since its operation, there have been more than 50 peer reviewed studies conducted to evaluate InSite from various angles. It should be noted that none of the studies have been able to highlight any adverse effects. The following are some of their findings:

- $\quad$ No evidence of increased drug trafficking or crime related to drug use (Wood et al., 2006).

- Fewer risky injections (Kerr et al., 2005).

- Increased probability of initiating and maintaining addiction treatment (DeBeck et al., 2011).

- $\quad 35 \%$ drop in overdose death in the vicinity of InSite (Marshall et al., 2011).

- $\quad$ Large-scale reductions in public drug use (Wood et al., 2004).

- $\quad$ Large reductions in publicly discarded syringes and syringe sharing (Wood et al., 2004).

Furthermore, it has been ascertained that InSite

- Has been a key venue for obtaining care related to the treatment of infections (Small et al., 2008).

- Has served as a cornerstone for safer injection education (Wood et al., 2005).

- Has provided safety and refuge from the various dangers associated with street-based drug scenes (Fairbairn et al., 2008).

- Has successfully managed to play a role in controlling overdose and reducing the burden on emergency services (Kerr et al., 2006).

- Has attracted IDUs who are at increased risk of HIV infection and overdose (Wood et al., 2005).

In addition to the positive accounts mentioned above, the facility has proved to be cost-effective, providing a subsequent amount of net savings to the publically funded health care system (Andresen \& Boyd, 2010; Andresen \& Jozaghi, 2012; Bayoumi \& Zaric, 2008; Des Jarlais et al., 2008; Pinkerton, 2010, 2011). Furthermore, numerous studies have demonstrated the cost-saving measures of SIFs in the Canadian settings if they are expanded (Bayoumi \& Strike, 2012; Jozaghi, 2014; Jozaghi et al., 2013, 2014). 
Ironically, however, the operation and scientific evaluation of the Vancouver's safe injection site has been challenged by Canada's Conservative federal government publically: Both in the media and in courts (Wood et al., 2008). In effect, despite the support of the City of Vancouver and BC's provincial government, the federal government, since May 2008, has leaned towards closing the facility (Rennie, 2011). The federal government has rejected the scientific evidence supporting InSite, arguing in turn that the facility fosters addictions (Rennie, 2011). According to former federal health minister, Tony Clement, "we have given it due process, we've looked at all the evidence, and our position is that the exemption should not be continued. . . in terms of public policy, it was clear: a better thing to do is to treat people, to prevent people from going on the drugs in the first place" (Rennie, 2011, p. S1). Tackling the constant threat of closure from the federal government, the operators of InSite were compelled to take the federal government of Canada to the Supreme Court of British Columbia in 2007. The Supreme Court of $\mathrm{BC}$, and in the later legal battle the British Columbia Court of Appeal, ruled that InSite should remain open (PHS v. Canada, 2010; Pitfield, 2008). Both courts ruled that " Controlled Drugs and Substances Act in Canada is unconstitutional as it pertains to InSite because the closure of the program under the Act would impede injection drug users from receiving lifesaving healthcare"' (Small, 2010, p. 2).

Despite these rulings in favor of InSite, the federal government decided to pursue the case further and take it to the Supreme Court of Canada (2011). The Supreme Court of Canada finally ruled in favor of InSite on September 2011 (Andresen \& Jozaghi, 2012). The rulings highlighted the legal implications for the establishment and expansion of similar SIFs in Canada in the near future (Jozaghi, 2012a). The ruling states: " On future applications, the Minister must exercise that discretion within the constraints imposed by the law and the Charter, aiming to strike the appropriate balance between achieving public health and public safety" (Supreme Court of Canada, 2011). In light of the Supreme Court of Canada's unanimous decision on Insite, recognizing the right of such facilities as a necessary medical facility for marginalized populations, the Canadian federal government introduced the Bill C-65 (now Bill C-2) - an act to amend the Controlled Drugs and Substances Act. Many have raised concern about the Bill $C$-2 because they believe that the legislation ignores the benefits of SIFs, in the interest of community safety, restricting the access to those who need it the most. Bill C-2 is now proposing 26 new kinds of criterion that must be met before an exemption can be granted by the Minister of Health. However, placing an emphasis on the "expression of community support or opposition" imposes a significant barrier to the marginalized population in terms of accessing the life-saving healthcare services. Ultimately, Bill C-2 will make the most marginalized population facing the risk of overdose and infectious diseases dependent more on perception and feeling rather than on reliable and empirical evidence. The bill will not only pit the marginalized and vulnerable groups' rights against the general population, but it also facilitate the rise of voices of dissent based on a moral ideology and NIMBYism, the latter of which refers to the "not in my backyard" attitude.

Therefore, any expansion of SIFs in other Canadian cities need not to be conducted after consulting the community such as provincial, civic, and police officials essentially giving a veto to health care services to cities, police, community opponents, and Ministries of Public Safety. The benefit of SIFs are known, SIFs are effective in reducing injections in public: they simultaneously lower the rates of overdose fatalities and infectious diseases (Andresen \& Boyd, 2010; Broadhead et al., 2002; Kerr et al., 2007; Wood et al., 2005). Also, SIFs have not increased crime, drug dealing, public injection, public syringe disposal, or contributed to the disturbance of public order in any way (Drucker, 2006; Hathaway \& Tousaw, 2008; Stoltz et al., 2007). The federal government has the opportunity to revise its policy and base its legislation on the best scientific evidence available, while providing disease prevention services and supporting the marginalized members of society. Bill C-2 must recognize that the access to SIFs is a human rights issue that is based on the principles of harm reduction and proven efficient, evidence-based practices in public health. 


\section{References}

Andresen, M. A., \& Boyd, N. T. (2010). A cost-benefit and cost-effectiveness analysis of Vancouver's supervised injection facility. International Journal of Drug Policy, 21, 70-76.

Andresen, M. A., \& Jozaghi, E. (2012). The point of diminishing returns: An examination of expanding Vancouver's Insite. Urban Studies, 49, 3531-3544.

Bayoumi, A. M., \& Strike, C. (2012). Report of the Toronto and Ottawa Supervised Consumption Assessment Study. Toronto: University of Toronto.

Bayoumi, A. M., \& Zaric, G. S. (2008). The cost-effectiveness of Vancouver's supervised injection facility. Canadian Medical Association Journal, 179, 1143-1151.

Broadhead, R. S., Kerr, T., Grund, J. C., \& Altice, F. L. (2002). Safer injection facilities in North America: Their place in public policy and health initiatives. Journal of Drug Issues, 32, 329-355.

DeBeck, K., Kerr, T., Bird, L., Zhang, R., Marsh, D., Tyndall, M., Montaner, J., \& Wood, E. (2011). Injection drug use cessation and use of North America's first medically supervised safer injecting facility. Drug and Alcohol Dependence, 113, 172-176.

Des Jarlais, D. C., Arasteh, K., \& Hagan, H. (2008). Evaluating Vancouver's supervised injection facility: Data and dollars, symbols and ethics. Canadian Medical Association Journal, 179, 1105-1106.

Dooling, K., \& Rachlis, M. (2010). Vancouver's supervised injection facility challenges Canada's drug laws. Canadian Medical Association Journal, 182, 1440-1444.

Drucker, E. (2006). Insite: Canada's landmark safe injecting program at risk. Harm Reduction Journal, 3, 1-3.

Fairbairn, N., Small, W., Shannon, K., Wood, E., \& Kerr, T. (2008). Seeking refuge from violence in street-based drug scenes: Women's experiences in North America's first supervised injection facility. Social Science \& Medicine, 67, 817-823.

Fast, D., Small, W., Wood, E., \& Kerr, T. (2008). The perspective of injection drug users regarding safer injecting education delivered through a supervised injecting facility. Harm Reduction Journal, 5, 1-8.

Fischer, B., Rehm, J., \& Blitz-Miller, T. (2000). Injection drug use and preventive measures: A comparison of Canadian and Western European jurisdictions over time. Canadian Medical Association Journal, 162, 1709-1713

Hathaway, A. D., \& Tousaw, K. I. (2008). Harm reduction headway and continuing resistance: Insights from safe injection in the city of Vancouver. International Journal of Drug Policy, 19, 11-16.

Hyshka, E., Bubela, T., \& Wild, C. T. (2013). Prospects for scaling-up supervised injection facilities in Canada: The role of evidence in legal and political decision-making. Addiction, 108, 468-476.

Jozaghi, E. (2012a). The science versus the politics: The need for supervised injection facilities in Montreal, Canada. International Journal of Drug Policy, 23, 420-421.

Jozaghi, E. (2012b). 'A little heaven in hell': The role of a supervised injection facility in transforming place. Urban Geography, 33, $1144-1162$.

Jozaghi, E. (2014). A cost-benefit/cost-effectiveness analysis of an unsanctioned supervised smoking facility in the Downtown Eastside of Vancouver, Canada. Harm Reduction Journal, 11, 1-8.

Jozaghi, E., Reid, A. A., \& Andresen, M. A. (2013). A cost-benefit/cost-effectiveness analysis of proposed supervised injection facilities in Montreal, Canada. Substance Abuse Treatment, Prevention, and Policy, 8, 1-8.

Jozaghi, E., Reid, A. A., Andresen, M. A., \& Juneau, A. (2014). A cost-benefit/cost-effectiveness analysis of proposed supervised injection facilities in Ottawa, Canada. Substance Abuse Treatment, Prevention, and Policy, 9, 1-13.

Kerr, T., Small, W., Moore, D., \& Wood, E. (2007). A micro-environmental intervention to reduce the harms associated with drug-related overdose: Evidence from the evaluation of Vancouver's safer injection facility. International Journal of Drug Policy, 18 , $37-45$.

Kerr, T., Tyndall, M. W., Lai, C., Montaner, J. S. G., \& Wood, E. (2006). Drug-related overdose within a medically supervised safer injection facility. International Journal of Drug Policy, 17, 436-441. 
Kerr, T., Tyndall, M., Li, K., Montaner, J., \& Wood, E. (2005). Safer injection facility use and syringe sharing in injection drug users. Lancet, 366, 316-318.

Kerr, T., Wood, E., Palepu, A., Wilson, D., Schechter, M. T., \& Tyndall, M. W. (2003). Responding to an explosive HIV epidemic driven by frequently cocaine injection: Is there a role for safe injecting facilities? Journal of Drug Issues, 22, 579-608.

Marshall, B. D. L., Milloy, M. J., Wood, E., Montaner, J. S. G., \& Kerr, T. (2011). Reduction in overdose mortality after the opening of North America's first medically supervised safer injection facility: A retrospective population-based study. The Lancet, 377, $1429-1437$.

PHS Community Services Society v. Canada (Attorney General). (2010). British Columbia Court of Appeal. BCCA 15.

Pinkerton, S. D. (2010). Is Vancouver Canada's supervised injection facility cost-saving? Addiction, 105, 1429-1436.

Pinkerton, S. D. (2011). How many HIV infections are prevented by Vancouver Canada's supervised injection facility? International Journal of Drug Policy, 22, 179-183.

Pitfield, Justice I. (2008). PHS Community Services Society v. Attorney General of Canada: BCSC 661. The Supreme Court of British Columbia; 2008.

Rennie, S. (2011, May 13). No decision on InSite, court told. The Globe and Mail, pp. S1, S2.

Small, D. (2010). An appeal to humanity: Legal victory in favour of North America's only supervised injection facility: Insite. Harm Reduction Journal, 7, 1-3.

Small, W., Wood, E., Lioyd-Smith, E., Tyndall, M., \& Kerr, T. (2008). Accessing care for injection-related infections through a medically supervised injection facility: A qualitative study. Drug and Alcohol Dependence, 98, 159-162.

Stoltz, J.-A., Wood, E., Small, W., Li, K., Tyndall, M. W., \& Montaner, J. S. G. (2007). Changes in injecting practices associated with the use of a medically supervised safer injection facility. Journal of Public Health, 29, 35-39.

Supreme Court of Canada. (2011). Canada (Attorney General) v. PHS Community Services Society. In SCC 44 33556. Edited by Canada SC. Ottawa: Supreme Court of Canada.

Ti, L., Kerr, T.,Wood, E., Werb, D., DeBeck, K., Graham, D., \& Vann, P. (2013). Drug Situation in Vancouver. Vancouver: Urban Health Research Initiative of the British Columbia Centre for Excellence in HIV/AIDS

Wood, E., Kerr, T., Small, W., Li, K., Marsh, D. C., \& Montaner, J. S. G. (2004). Changes in public order after the opening of a medically supervised safer injection facility for illicit injection drug users. Canadian Medical Association Journal, 171, 731-734

Wood, E., Kerr, T., Tyndall, M. W., \& Montaner, J. S. G. (2008). The Canadian government's treatment of scientific process and evidence: Inside the evaluation of North America's first supervised injection facility. International Journal of Drug Policy, 19 , 220-225.

Wood, E., Tyndall, M. W., Li, K., Lioyd-Smith, E., Small, W., \& Montaner, J. S. G. (2005). Do supervised injection facilities attract higher-risk injection drug users? American Journal of Preventive Medicine, 29, 126-130.

Wood, E., Tyndall, M. W., Montaner, J. S. G., \& Kerr, T. (2006). Summary of findings from the evaluation of a pilot medically supervised safer injecting facility. Canadian Medical Association Journal, 175, 1399-1404. 